\title{
Response of Onion to Applied Potassium at Farmer's Scale Field
}

\author{
Amanpreet Kaur*, Balvir Kaur, Paramjit Kaur Sraw and Kuldeep Singh \\ Krishi Vigyan Kendra, Jalandhar, Punjab \\ *Corresponding author
}

\begin{abstract}
A B S T R A C T
Potassium $(\mathrm{K})$ is one of the major nutrients taken up by the plant in large quantities. Adequate amount of potassium is known to increase crop resistance to various diseases and also having important role in bulb formation in onion. An on farm trial was conducted to evaluate the effect of method of planting and different level of potassium in onion on Keywords the soils tested medium in $\mathrm{K}$ status, trial consists of four levels of Potassium replicated thrice in randomised block design. The four levels of potassium were as: $0 \mathrm{~kg} \mathrm{~K} \mathrm{~K}_{2} \mathrm{O} / \mathrm{ha}, 50$ $\mathrm{kg} \mathrm{K} 2 \mathrm{O} / \mathrm{ha}, 75 \mathrm{kgK}_{2} \mathrm{O} / \mathrm{ha}$ and $100 \mathrm{~kg} / \mathrm{ha}$. Experiment results indicated that all the yield contributing characters responded to applied potassium. Bulb yield also responded to potassium application. It increased from $320.7 \mathrm{q} / \mathrm{ha}$ to in the control plot to $366.6 \mathrm{q} / \mathrm{ha}$ in treatment where $100 \mathrm{~K} 2 \mathrm{O} / \mathrm{ha}$ was applied in 2012 and from $350 \mathrm{q} / \mathrm{ha}$ to $360.3 \mathrm{q} / \mathrm{ha}$ in 2013. TSS content also increased from 9.2 to $13.6 \%$ in 2012 and from 10.80 to 11.89 in 2013 with increase in application of potassium from $0 \mathrm{~kg} \mathrm{~K} 2 \mathrm{O} / \mathrm{ha}$ to $100 \mathrm{Kg} \mathrm{K}_{2} \mathrm{O}$. The behaviour of the onions regarding weight loss and sprouting stored at room temperature was recorded. It was observed that with increase in potash content there was decrease in moisture loss and sprouting. Highest sprouting percentage $(6.7 \%$ and $12.4 \%)$ at 30 and 90 DAS respectively was observed in control plots Sprouting was highest in control plots both at 30 and 90 days after storage.
\end{abstract}

\section{Introduction}

Onion (Allium cepa) is one of the commercially grown vegetable crops over the world. It belongs to family Alliaceas and grown for is pungency and flavour. It is also a good source of minerals phosphors and calcium. Besides this, it is also good source of proteins, carbohydrates, fats, thiamine Niacin and ascorbic acid. India is the second largest onion growing country with average yield of $10.38 \mathrm{~m} \mathrm{tha}^{-1}$. Although India account for about $16 \%$ of world production but it lags behind global average yield which is 18.08 mtha-1.(www.fao.org,2005). This may be due to imbalanced use of fertilizers resulting in low nutrient use efficiency (Kanwar and
Sekhon, 1998). Apart from nitrogen and phosphorus, Potassium is also an important nutrient needed in large quantities.It is removed in large quantities by onion and taken up by the plant in form of $\mathrm{K}^{+}$. Potassium plays important role in numerous roles in plant physiological and biochemical processes like photosynthesis, translocation of assimilates, protein synthesis, enhancing enzyme activities and maintenance of water balance of the plants which increases the yield and quality of onion (Marschner, 2012; Yadav et al., 2002). It is also known to decrease the post harvest loss and increase the storage life of onion. But it has been observed that It is 
generally omitted by the farmers especially in Punjab. This may be due to that Punjab soils are generally rich in $\mathrm{K}$ containing minerals and its application is recommended only on the basis of soil test in other field crops. But, it has been reported that most of the root crops respond to potassium application especially on the soils tested medium in $\mathrm{K}$ status because they remove more potassium from soils than other crops. So, the Productivity of onion can be increased with application of recommended dose of potassium application. Keeping above in view, an On Farm Trial (OFT) was conducted at farmer's scale field to know the effect of potassium application on yield and some quality parameters of onion.

\section{Materials and Methods}

The On Farm Trial (OFT) was conducted at farmer's scale field in the district, Jalandhar to study the effect of potash on yield and quality of onion during the year 2012 and 2013 in Rabi season. Krishi Vigyan Kendra, Nurmahal, Jalandhar is geographically situated at $31^{\circ} 09^{\prime} \mathrm{N}$ latitude, 75'59' E longitude and at an altitude of about $237 \mathrm{~m}$ above mean sea level. The climate of the region is extremely hot during the summer and cold during winter. The soil samples were collected from 0-15 cm depth before start of the experiment to determine soil chemical properties. The soil of the experimental site was sandy loam in texture having $\mathrm{pH}$ 8.3, EC. $0.14 \mathrm{ds} / \mathrm{m}$, low in organic carbon content $(0.35 \%)$, low in available $\mathrm{N}(90 \mathrm{~kg} / \mathrm{ha})$, High in available $\left.\mathrm{P}_{2} \mathrm{O}_{5}(23.7 \mathrm{~kg} / \mathrm{ha})\right)$ and medium in available $\mathrm{K}_{2} \mathrm{O}(116 \mathrm{~kg} / \mathrm{ha}$ ) (Table 1). The on farm trial was laid out in randomized block design with three replications and four levels of potassium fertilizer viz.: $0 \mathrm{~kg} / \mathrm{ha}, 50 \mathrm{~kg} / \mathrm{ha}$, $75 \mathrm{~kg} / \mathrm{ha}$ and $100 \mathrm{~kg} / \mathrm{ha}$. The nutrients applied other than potassium were FYM 20t/ha, $40 \mathrm{kgN}$ and $20 \mathrm{~kg} \mathrm{P} / \mathrm{ha}$. All these nutrients were applied according to package of practice recommended by Punjab Agricultural
University, Ludhiana for cultivation of vegetables. The nursery of onion (cv. Punjab Naroya) was sown using seed rate $10 \mathrm{~kg} \mathrm{ha}^{-}$ ${ }^{1}$ in last week of October. The transplanting of the onion seedlings in the field was done in first fortnight of January in both the years following $15 \times 7.5 \mathrm{~cm}$ row to row spacing and plant to plant spacing. Nitrogen was applied in the form of urea and phosphorus was applied in the form diammonium phosphate. The sources of potassium used were murriate of potash. Whole phosphorus, sulphur and half nitrogen was applied before transplanting and remaining nitrogen was applied was after four weeks of transplanting. Potassium was also applied at time of transplanting except treatment T4 where, it is applied in two equal splits; $1 / 2$ at the time of transplanting and remaining $1 / 2 \quad 20$ DAT. Other crop management practices were also followed according to package of practice. The uprooting of the bulbs was done manually in the first week of May during both the years. After harvesting, the bulbs were cured and then leaves were cut $1-2 \mathrm{~cm}$ above the neck and bulb yield was recorded. Weed control efficiency was also calculated 60 DAS and at harvest. The data on fresh plant height $(\mathrm{cm})$, Neck thickness, Number of leaves per plant, bulb weight (g),sprouting (\%),Physiological Weight loss (30 days after harvest) and Physiological Weight loss (90s days after harvest). The data collected on various parameters under study were statistically analyzed with CPCS1 and comparisons were made at 5 per cent level of significance.

\section{Results and Discussion}

\section{Effect of potassium on yield and yield contributing characters}

It has been observed that all the yield contributing characters except number of leaves and yield responded significantly to application of potassium (Table 1) in both the 
years. In first year of the study, plant height increased from $53.6 \mathrm{~cm}$ at $0 \mathrm{~kg} \mathrm{~K} \mathrm{O} / \mathrm{ha}$ to $69.6 \mathrm{~cm}$ at $100 \mathrm{~kg} \mathrm{~K}_{2} \mathrm{O} / \mathrm{ha}$. However, the increase in plant height is only significant with application of $50 \mathrm{~kg} \mathrm{~K} 2 \mathrm{O} / \mathrm{ha}$. Similarly, in 2013 highest plant height $(66.6 \mathrm{~cm})$ was recorded in the treatment which received 100 $\mathrm{Kg} \mathrm{K} 2 \mathrm{O} /$ ha which is closely followed by the treatment received $75 \mathrm{Kg} \mathrm{K} 2 \mathrm{O} / \mathrm{ha} \mathrm{t}(66.3 \mathrm{~cm})$. Lowest plant height $(60 \mathrm{~cm})$ was observed in the control plots where no $\mathrm{K}$ was applied. This may be due to the fact that availability of potassium may have increased the plant utilization of nitrogen which helped in increase in plant height as reported by Salam et al., (2004) and Islam et al., (2008). Highest average number of leaves per plot was recorded with highest level of applied K. Baniony (2006) also documented that number of leaves/plant was increased with increase in potassium level. Similarly, neck thickness at the time of harvest was recorded to be lowest in control treatment and increased significantly with application of $75 \mathrm{~kg} \mathrm{~K}_{2} \mathrm{O} / \mathrm{ha}$ in the year 2012. However, in the next year, increase in neck thickness was not significant with application of $50 \mathrm{~kg} \mathrm{~K}_{2} \mathrm{O}$ and $75 \mathrm{~kg}$ $\mathrm{K}_{2} \mathrm{O} /$ ha. Highest neck thickness in this year $(11.89 \mathrm{~cm})$ was observed with application of $100 \mathrm{~kg} \mathrm{~K} / \mathrm{ha}$. These results are in line with the results of Yadav et al., (2003).

Application of potassium had also significant effect on bulb weight and bulb yield. It was found that maximum bulb weight $(75 \mathrm{gm})$ was found with application of $100 \mathrm{~kg} \mathrm{~K} \mathrm{~K}_{2} \mathrm{O} / \mathrm{ha}$ followed by $(74 \mathrm{gm})$ with $75 \mathrm{~kg} \mathrm{~K}_{2} \mathrm{O}$ while the minimum average bulb weight $(57 \mathrm{gm})$ was observed in control treatment where potassium was not applied in 2012. Similarly in 2013, bulb weight increased from $65.0 \mathrm{gm}$ at $0 \mathrm{~kg} \mathrm{~K}$ to $70 \mathrm{gm}$ at $100 \mathrm{~kg} \mathrm{~K} / \mathrm{ha}$. However, the increase was only significant up to $50 \mathrm{~kg}$ $\mathrm{K} / \mathrm{ha}$. Further increase with $75 \mathrm{~kg} \mathrm{~K}$ and 100 $\mathrm{Kg} \mathrm{K} /$ ha was not significant. Increase in bulb weight with increase in levels of potassium was also found by Ghafoor et al., (2003). Bulb yield for two years revealed that onion yield responded to applied potassium. It increased from $320.7 \mathrm{~kg} / \mathrm{ha}$ to $366.6 \mathrm{~kg} / \mathrm{ha}$ in 2012 as level of potassium increased from 0 to $100 \mathrm{~kg} / \mathrm{ha}$. However, the increase was significant only up to $75 \mathrm{~kg} / \mathrm{ha}$. Increase in yield with application of $75 \mathrm{~kg} \mathrm{~K}_{2} \mathrm{O} / \mathrm{ha}$ was also reported by Kahlon et al., (2011). In 2013, the increase of the yield was significant only up to $50 \mathrm{~kg} \mathrm{~K} 2 \mathrm{O} / \mathrm{ha}$. Application of 75 $\mathrm{kg}$ and $100 \mathrm{~kg} \mathrm{~K} \mathrm{~K}_{2} \mathrm{O} / \mathrm{ha}$ did not increased the yield significantly. However the total of $2.94 \%$ increases in yield was observed with $100 \mathrm{~kg} \mathrm{~K} 2 \mathrm{O} /$ ha over the control plot. Yadav et al., (2003) also reported highest bulb yield with highest potassium rate.

Potassium had also showed response on different grade size of onions. Data presented in tables 2 and 3 indicated that with increase in level of potassium percentage of bigger size onion $(45 \mathrm{~mm}$ and $50 \mathrm{~mm}$ ) increased from $25 \%$ (45 $\mathrm{mm})$ and 35\%(50 mm) without potassium application to $27.8 \%(45 \mathrm{~mm})$ and $37.2 \%(50 \mathrm{~mm})$ at $100 \mathrm{~kg} \mathrm{~K}_{2} \mathrm{O} / \mathrm{ha}$. Similarly, In 2013, percentage of $25 \mathrm{~mm}$ size onion decreased from 10 to $7 \%$ as $\mathrm{K}$ level increased from 0 to $100 \mathrm{kgK} / \mathrm{ha}$ and percentage of 45 $\mathrm{mm}$ grade size onion increased from 30 to 36.1 with increase in levels of $\mathrm{K}$ and $50 \mathrm{~mm}$ grade size onion increased from $35.2 \%$ to $36.5 \%$ as $\mathrm{K}$ level increased from $0 \mathrm{Kg} \mathrm{K}_{2} \mathrm{O}$ to $100 \mathrm{Kg} \mathrm{K}_{2} \mathrm{O} / \mathrm{ha}$.

Uptake of $\mathrm{K}$ increased with increase in successive rates of Potassium in both the years of study. It increased significantly from $22.1 \mathrm{~kg} / \mathrm{ha}$ at $0 \mathrm{~kg} \mathrm{~K} \mathrm{O}_{2} \mathrm{O}$ to $40.2 \mathrm{~kg} / \mathrm{ha}$ at $100 \mathrm{~kg}$ $\mathrm{K}_{2} \mathrm{O} /$ ha (Table 1). However, in 2013 it increased from $24.1 \mathrm{~kg} / \mathrm{ha}$ to $35.4 \mathrm{Kg} / \mathrm{ha}$ at 0 $\mathrm{Kg} \mathrm{K}_{2} \mathrm{O}$ and $100 \mathrm{~kg} \mathrm{~K}_{2} \mathrm{O} / \mathrm{ha}$, respectively. Kumar et al., (2001) noticed that the uptake of potassium $(78.60 \mathrm{~kg} / \mathrm{ha})$ increased with increase in application of potassium. 
Table.1 Chemical characteristics of surface soil of experimental site

\begin{tabular}{|l|l|l|l|l|l|}
\hline $\mathrm{pH}$ & $\mathrm{EC}(\mathrm{ds} / \mathrm{m})$ & $\mathrm{OC}(\%)$ & $\begin{array}{l}\text { Available } \\
\mathrm{N}(\mathrm{kg} / \mathrm{ha})\end{array}$ & $\begin{array}{l}\text { Available } \\
\mathrm{P}(\mathrm{kg} / \mathrm{ha})\end{array}$ & $\begin{array}{l}\text { Available } \\
\mathrm{K}(\mathrm{kg} / \mathrm{ha}\end{array}$ \\
\hline 8.3 & 0.14 & 0.35 & 90 & 23.7 & 116 \\
\hline
\end{tabular}

Table.2 Effect of potassium on yield and yield contributing characters of onion

\begin{tabular}{|c|c|c|c|c|c|c|}
\hline Treatments & $\begin{array}{l}\text { Plant } \\
\text { Height } \\
\text { (cm) }\end{array}$ & $\begin{array}{l}\text { No of } \\
\text { leaves }\end{array}$ & $\begin{array}{c}\text { Neck } \\
\text { thickness } \\
(\mathrm{cm})\end{array}$ & $\begin{array}{l}\text { Bulb weight } \\
\text { (gm) }\end{array}$ & $\begin{array}{l}\text { Yield } \\
\text { (q/ha) }\end{array}$ & $\begin{array}{c}\text { K uptake } \\
(\mathrm{kg} / \mathrm{ha})\end{array}$ \\
\hline \multicolumn{7}{|l|}{2012} \\
\hline $\mathrm{T}_{1}$ & 55.6 & 5.0 & 9.8 & 57.0 & 320.7 & 22.1 \\
\hline $\mathrm{T}_{2}$ & 66.3 & 7.5 & 10.9 & 70.1 & 355.3 & 28.2 \\
\hline $\mathrm{T}_{3}$ & 68.4 & 8.5 & 11.7 & 74.0 & 364.5 & 33.8 \\
\hline $\mathrm{T}_{4}$ & 69.6 & 8.8 & 11.8 & 75.0 & 366.6 & 40.2 \\
\hline $\mathrm{CD}(\mathrm{p}=0.0$ & 3.2 & NS & 0.17 & 4.3 & 7.1 & 4.5 \\
\hline \multicolumn{7}{|l|}{2013} \\
\hline $\mathrm{T}_{1}$ & 60.0 & 6.2 & 10.80 & 65.0 & 350.0 & 24.1 \\
\hline $\mathrm{T}_{2}$ & 65.0 & 6.8 & 10.84 & 67.9 & 355.8 & 28.8 \\
\hline $\mathrm{T}_{3}$ & 66.3 & 7.0 & 10.90 & 69.3 & 359.0 & 30.3 \\
\hline $\mathrm{T}_{4}$ & 66.6 & 7.5 & 11.89 & 70.0 & 360.3 & 35.4 \\
\hline $\mathrm{CD}(\mathrm{p}=0.0$ & 1.8 & $\mathrm{NS}$ & 0.18 & 2.08 & 4.3 & 3.2 \\
\hline
\end{tabular}

Table.3 Effect of potassium application on different grade sizes of onion(\%)(2012)

\begin{tabular}{|c|c|c|c|c|}
\hline Treatments & \multicolumn{4}{|c|}{ Levels of $\mathrm{K}_{2} \mathrm{O}(\mathrm{kg} / \mathrm{ha})$} \\
\hline $\begin{array}{c}\text { Grade size } \\
(\mathrm{mm})\end{array}$ & 0 & 50 & 75 & 100 \\
\hline 25 & $10(3.26)$ & $8 \quad(2.84)$ & $7.8(2.84)$ & $7.0(2.56)$ \\
\hline 35 & $30(9.6)$ & $29.8(10.58)$ & $29.5(10.75)$ & $28.0(10.26)$ \\
\hline 45 & $25(8.0)$ & $25.7(9.13)$ & $26(9.48)$ & $27.8(10.19)$ \\
\hline 50 & $35(11.2)$ & $36.5(12.96)$ & $36.7(13.38)$ & $37.2(13.63)$ \\
\hline $\begin{array}{l}\text { Total yield } \\
\text { (t/ha) }\end{array}$ & 32.06 & 35.51 & 36.46 & 36.64 \\
\hline
\end{tabular}

Table.4 Effect of potassium application on different grade sizes of onion(\%)(2013)

\begin{tabular}{|l|l|l|l|l|}
\hline Treatments & \multicolumn{4}{|l|}{ Levels of $\mathrm{K}_{2} \mathrm{O}(\mathrm{kg} / \mathrm{ha})$} \\
\hline $\begin{array}{c}\text { Grade size } \\
(\mathrm{mm})\end{array}$ & 0 & 50 & 75 & 100 \\
\hline 25 & $7.0(2.45)$ & $6.3(2.24)$ & $6.1(2.18)$ & $6.0(2.16)$ \\
\hline 35 & $28(9.8)$ & $22.3((7.93)$ & $22.0(7.9)$ & $21.7(7.82)$ \\
\hline 45 & $30(10.5)$ & $35.4(12.59)$ & $35.5(12.74)$ & $36.1(13)$ \\
\hline 50 & $35.2(12.25)$ & $36.1(12.84)$ & $36.4(13.06)$ & $36.5(13.1)$ \\
\hline $\begin{array}{l}\text { Total yield } \\
(\mathrm{t} / \mathrm{ha})\end{array}$ & 35.0 & 35.58 & 35.90 & 36.03 \\
\hline
\end{tabular}

Value in parenthese denote yield of respective grade size 
Table.5 Effect of potassium on quality parameters of onion

\begin{tabular}{|c|c|c|c|c|c|}
\hline Treatments & $\begin{array}{l}\text { Total Soluble } \\
\text { Solids }\end{array}$ & \multicolumn{2}{|c|}{ Sprouting $(\%)$} & \multicolumn{2}{|c|}{ Physiological Weight loss (\%) } \\
\hline \multicolumn{6}{|c|}{2012} \\
\hline & & 30 DAS & 90 DAS & 30 DAS & 90 DAS \\
\hline $\mathrm{T}_{1}$ & 9.2 & 6.7 & 12.4 & 12.27 & 29.6 \\
\hline $\mathrm{T}_{2}$ & 11.1 & 3.0 & 7.5 & 10.70 & 23.2 \\
\hline $\mathrm{T}_{3}$ & 12.1 & 2.0 & 4.4 & 8.77 & 19.1 \\
\hline $\mathrm{T}_{4}$ & 13.6 & 1.8 & 4.3 & 8.73 & 18.6 \\
\hline $\mathrm{CD}(\mathrm{p}=0.05)$ & 0.52 & 0.81 & 1.19 & 1.62 & 2.12 \\
\hline \multicolumn{6}{|c|}{2013} \\
\hline $\mathrm{T} 1$ & 10.4 & 4.4 & 10.3 & 12.46 & 26.4 \\
\hline $\mathrm{T} 2$ & 10.8 & 3.3 & 9.8 & 12.23 & 25.7 \\
\hline $\mathrm{T} 3$ & 11.0 & 2.5 & 8.8 & 11.10 & 23.6 \\
\hline $\mathrm{T} 4$ & 11.8 & 2.2 & 7.5 & 9.45 & 21.0 \\
\hline $\mathrm{CD}(\mathrm{p}=0.05)$ & 0.43 & 0.17 & 0.77 & 1.21 & 1.23 \\
\hline
\end{tabular}

\section{Quality parameters}

Some of quality parameters of viz. Total Soluble Salts (TSS), sprouting percentage at 30 days after storage (DAS) and 90 DAS and physiological moisture loss at 30 and 90 DAS are depicted on table 2. TSS content increased significantly with increase in levels of applied potassium. It from 9.2 to $13.6 \%$ as potassium level increased from 0 to $100 \mathrm{~kg} \mathrm{~K} \mathrm{O} / \mathrm{h}$ in 2012. However, in next year, it increased from $10.4 \%$ in control plot to $10.8 \%$ at $50 \mathrm{~kg}$ $\mathrm{K}_{2} \mathrm{O} /$ ha which was not a significant improvement. But further increase to $11 \%$ at $75 \mathrm{~kg} \mathrm{~K}_{2} \mathrm{O}$ and $11.8 \%$ at $100 \mathrm{~kg} \mathrm{~K} \mathrm{~K}_{2} \mathrm{O} / \mathrm{ha}$ was significant. Yadav et al., (2002) also recorded higher TSS with application of $150 \mathrm{~kg}$ $\mathrm{K}_{2} \mathrm{O} / \mathrm{ha}$.

Highest sprouting percentage $(6.7 \%$ and 12.4 $\%)$ at 30 and 90 DAS respectively was observed in control plots. Minimum sprouting percentage at both the storage period was observed with highest level of $\mathrm{K}$ application. Similar results were observed in next cropping season (Table 4) where sprouting decreased to $50 \%$ and $27 \%$ with application of $100 \mathrm{~kg} \mathrm{~K}_{2} \mathrm{O} / \mathrm{ha}$ over that of control plot at
30 and 90 DAS, respectively. It is also depicted in data $\mathrm{K}$ helps in maintaining the moisture of stored onion. At 30 DAS, the physiological loss in moisture is highest $(12.27 \%)$ in control treatments. It decreased with increase in applied potassium. Similarly, After 90 days after storage, physiological weight loss decreased from $29.6 \%$ to 18.6 and 26.4 to $21 \% \%$ as level of $\mathrm{K}$ increased from 0 to $100 \mathrm{~kg} \mathrm{~K} \mathrm{~K}_{2} \mathrm{O} / \mathrm{ha}$ in 2012 and 2013 respectively.

It may be concluded from the above data that onion responded to applied potassium on sandy loam soil testing medium in available potassium. Maximum response in terms of (34.6 q/ha) was observed with application of $50 \mathrm{~kg} \mathrm{~K}_{2} \mathrm{O} / \mathrm{ha}$ in first year of study. Thereafter, the response was 9.2 and $2.1 \mathrm{q} / \mathrm{ha}$ with successive increase in level of potassium, however, in the next year although the bulb yield increased but crop responded less as compared to the previous year. The maximum response in yield was $5.8 \mathrm{q} / \mathrm{ha}$ with application of $50 \mathrm{~kg} \mathrm{~K} \mathrm{~K}_{2} \mathrm{O} / \mathrm{ha}$ over control, $3.2 \mathrm{q} / \mathrm{ha}$ over $75 \mathrm{Kg} \mathrm{K}_{2} \mathrm{O}$ and $1.3 \mathrm{q} /$ ha over $100 \mathrm{Kg} \mathrm{K} 2 \mathrm{O} / \mathrm{ha}$. Quality of onion in terms of TSS, Sprouting percentage, physiological 
weight loss \% crop had also improved in our study with application potassium. Minimum sprouting percentage at both the storage period was observed with highest level of $\mathrm{K}$ application.

\section{References}

Bassiony. 2006. Effect of Potassium Fertilization on Growth, Yield and Quality of Onion Plants. J. Appl. Sci. Res., 2(10): 780-785, 2006.

Ghaffoor, A.M.S., Jilani, G., Khaliq and K. Waseem. 2003. Effect of different NPK levels on the growth and yield of three onion (Allium cepa L.) varieties. Asian J. Plant Sci., 2(3): 342-346.

Islam, M.A., A.T.M. Shamsuddoha, M.S.I., Bhuiyan and Miyza Hasanuzzaman. 2008. Response of Summer Onion to Potash and its Application Methods. American-Eurasian J. Agron., 1(1): 1015.

Kahlon, M.S., Singh, C.B. and Sekhon, N.K. 2011. Response of onion to irrigation and potassium application. Res. on
Crops, 12(2): 539-544.

Kanwar, J.S. and Sekhon, G.S. 1998. Nutrient Management for Sustainable Intensive Agriculture. Fert. News, 43: 33-40.

Kumar, A., Ranbir Singh and Chhillar, R.K. 2001. Influence of nitrogen and potassium application on growth, yield and nutrient uptake by onion (Allium cepa). Indian J. Agron., 46(4): 742-746.

Marschner, P. 2012. Marschner's Mineral Nutrition of Higher Plants, Third Edition. Academic Press, Elsevier.

Singh, S.P. and Verma, A.B. 2001. Response of onion to potassium application. Ind. J. Agron,., 46: 185

Yadav, R.L., Sen, N.L. and Yadave, B.L. 2003. Response of onion to nitrogen and potassium fertilization under semiarid condition of Rajasthan. Indian. J. Hort., 6: 176-78.

Yadav, R.L., Sen, N.L., Fageria, M.S. and Dhaka, R.S. 2002. Effect of nitrogen and potassium fertilization on quality bulb production of onion. Haryana $J$. Hort. Sci., 31(3\&4): 297-298

\section{How to cite this article:}

Amanpreet Kaur, Balvir Kaur, Paramjit Kaur Sraw and Kuldeep Singh. 2017. Response of Onion to Applied Potassium at Farmer's Scale Field. Int.J.Curr.Microbiol.App.Sci. 6(7): 24912496. doi: https://doi.org/10.20546/ijcmas.2017.607.353 